\title{
1939-1940 WPA Archaeological Collections from Ancestral Caddo Sites in Nacogdoches County, Texas
}

Timothy K. Perttula

Heritage Research Center, Stephen F. Austin State University

Follow this and additional works at: https://scholarworks.sfasu.edu/ita

Part of the American Material Culture Commons, Archaeological Anthropology Commons, Environmental Studies Commons, Other American Studies Commons, Other Arts and Humanities Commons, Other History of Art, Architecture, and Archaeology Commons, and the United States History Commons

Tell us how this article helped you.

This Article is brought to you for free and open access by the Center for Regional Heritage Research at SFA ScholarWorks. It has been accepted for inclusion in Index of Texas Archaeology: Open Access Gray Literature from the Lone Star State by an authorized editor of SFA ScholarWorks. For more information, please contact cdsscholarworks@sfasu.edu. 


\section{9-1940 WPA Archaeological Collections from Ancestral Caddo Sites in Nacogdoches County, Texas}

\section{Creative Commons License}

\section{(c) (1) \&}

This work is licensed under a Creative Commons Attribution-NonCommercial 4.0 International License 


\title{
1939-1940 WPA Archaeological Collections from Ancestral Caddo Sites in Nacogdoches County, Texas
}

\author{
Timothy K. Perttula
}

\section{Introduction}

Gus Arnold identified and recorded a number of ancestral Caddo sites during his 1939-1940 WPAsponsored archaeological survey of East Texas (Im 1975). The artifact collections at the Texas Archeological Research Laboratory at The University of Texas at Austin (TARL), especially the ceramic sherd assemblages since Arnold typically collected substantial sherd samples from plowed fields, have been recently documented from 10 sites in the Attoyac, Ayish, and Palo Gaucho bayou basins in San Augustine County (Perttula 2015a, 2016), sherds from the Jonas Short mound site (41SA101) in San Augustine County (Perttula and Walters 2016), and 13 Caddo sites in the Patroon, Palo Gaucho, and Housen bayous in Sabine County (Perttula 2015b). In this article, I continue with the ceramic sherd documentation effort, but I am concerned with the analysis of sherd collections from three Caddo sites in the Bayou La Nana, King Creek, and Bayou Loco drainages in Nacogdoches County, namely Hill Place (41NA5), J. B. Dorsey (41NA6), and Deshazo (41NA13) (Figure 1).

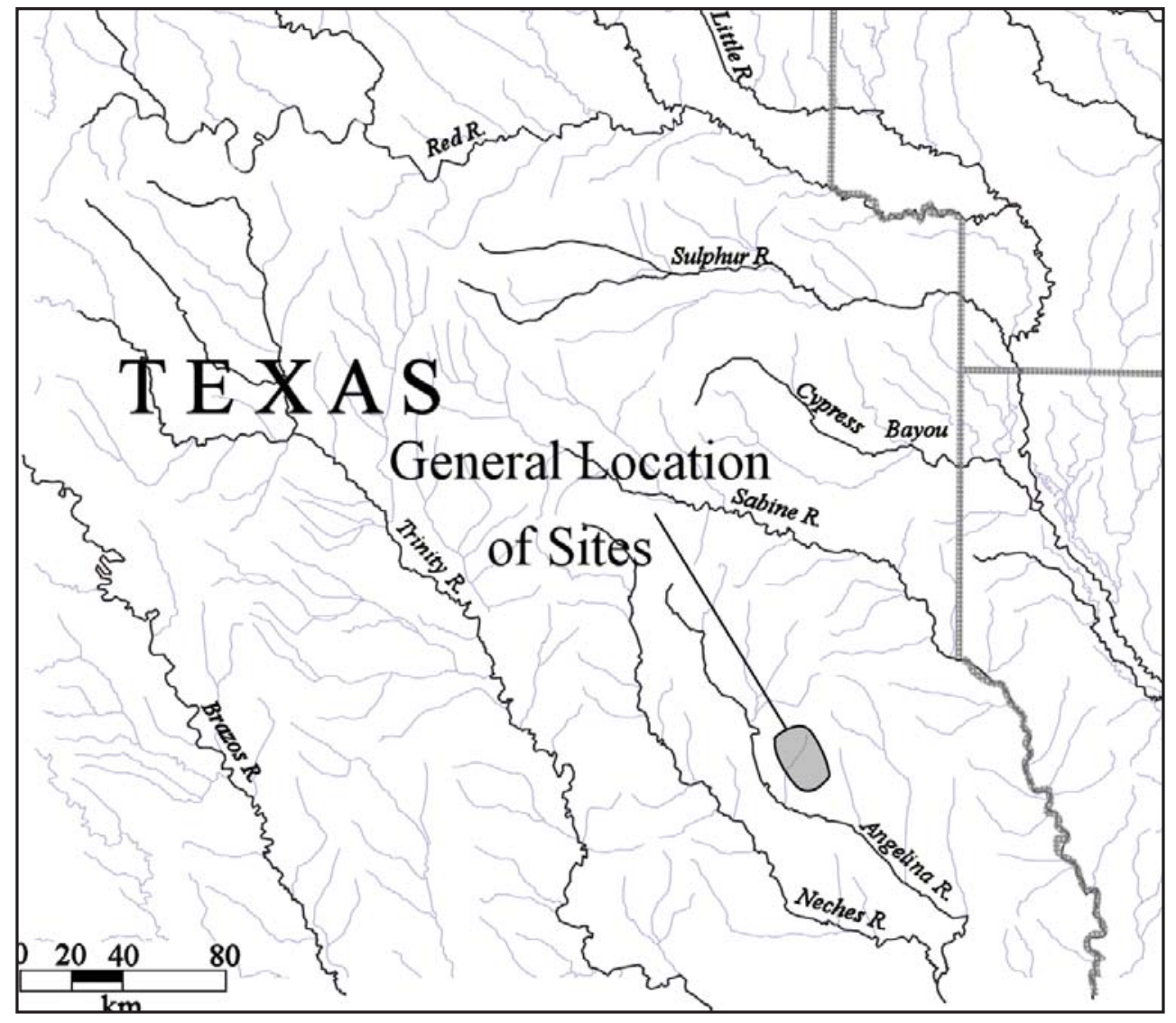

Figure 1. General location of 1939-1940 WPA archaeological sites in Nacogdoches County in East Texas. 


\section{Hill Place (41NA5)}

Arnold recorded the Hill Place site (ET-628) on Bayou La Nana in December 1939. He described it as a large (5 acres) settlement on an upland ridge. Dr. Tom Middlebrook has suggested that the Hill Place site may spatially overlap with the Buddy Still Farm site (41NA4) and another possible locality called the Appleby Bead site/Rudisell Farm site identified by Robert L. Turner, Jr.; Turner recovered approximately 120 glass beads from this locality.

Arnold collected 196 aboriginal ceramic vessel sherds and several dart points from the surface of the site at that time, but only 95 ancestral Caddo vessel sherds were available for analysis. The TARL inventory on file included 122 plain sherds and 74 decorated sherds; the differences are a result of the fact that (1) almost all the plain sherds from the Hill Place site remain in bulk storage and were not accessible for study, and (2) there are more decorated sherds present in the assemblage compared to earlier inventories.

The 95 sherds available for study are from both grog-tempered (67 percent) and bone-tempered (33 percent) ceramic vessels (Table 1), with roughly comparable proportions among the utility ware and fine ware sherds. Of the 89 decorated sherds, 91 percent are from utility wares. Presuming that there are 122 plain sherds from the site, as based on a TARL inventory, the plain to decorated sherd ratio for the assemblage is 1.37 .

Table 1. Ancestral Caddo ceramic wares from the WPA archaeological survey investigations at the Hill Place site.

\begin{tabular}{lccc}
\hline Ware & Grog-tempered & Bone-tempered & N \\
\hline Plain & 5 & 1 & 6 \\
Utility & 54 & 27 & 81 \\
Fine & 5 & 3 & 8 \\
\hline Totals & 64 & 31 & 95 \\
\hline
\end{tabular}

Approximately 35 percent of the decorated sherds in the Hill Place assemblage have brushing marks, and another 4.5 percent have brushed decorative elements in combination with either appliqued or incised elements (Table 2). The brushed-appliqued sherd may be from either a Pease Brushed-Incised or Reavely Brushed-Incised vessel (see Hart 1982, 2014; Suhm and Jelks 1962). The brushed to other wet paste sherd ratio for the assemblage is a low 0.71 .

Table 2. Decorative methods and elements in the ancestral Caddo ceramic wares from the WPA archaeological survey investigations at the Hill Place site.

Decorative method/

$\operatorname{Rim}$

Body $\mathrm{N}$

Decorative element

\section{Utility Ware}

\section{Appliqued}

diagonal opposed appliqued ridges

1

\section{Brushed}

horizontal brushed

overlapping brushed

parallel brushed

$\begin{array}{lll}2 & - & 2 \\ - & 1 & 1 \\ - & 28 & 28\end{array}$


Table 2. Decorative methods and elements in the ancestral Caddo ceramic wares from the WPA archaeological survey investigations at the Hill Place site, cont.

\begin{tabular}{l|ll}
$\begin{array}{l}\text { Decorative method/ } \\
\text { Decorative element }\end{array}$ & Rim & Body \\
\hline
\end{tabular}

\section{Utility Ware, cont.}

Brushed-Appliqued

opposed brushed and straight appliqued fillet

Brushed-Incised

parallel brushed-incised lines and marks

Incised

diagonal incised lines

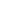

horizontal incised lines

1

1

parallel incised lines

5

5

parallel and diagonal hatched incised lines

$-$

\section{Incised-Punctated}

horizontal incised lines with crescent-shaped

fingernail punctations between the lines

horizontal incised panels with tool punctated row in each panel

incised triangle filled with tool punctated rows

\section{Punctated}

fingernail punctated rows

tool punctated rows

$-$

16

16

\section{Trailed}

parallel trailed lines

\section{Fine Ware}

\section{Engraved}

curvilinear engraved lines

curvilinear and opposed engraved lines, one line

with excised tick marks

diagonal engraved lines

horizontal engraved lines

horizontal and diagonal engraved lines

parallel engraved lines

parallel lines, one with excised tick marks and a cross-

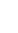

hatched curvilinear zone

straight engraved line

\begin{tabular}{lll}
- & 1 & 1 \\
- & 1 & 1 \\
1 & - & 1 \\
1 & - & 1 \\
1 & - & 1 \\
- & 1 & 1 \\
- & 1 & 1 \\
- & 1 & 1 \\
\hline 16 & 73 & 89 \\
\hline
\end{tabular}

Totals 
Sherds with simple geometric incised decorative elements comprise 19 percent of the decorated sherds (see Table 2). One has parallel and diagonal incised lines (Figure 2a). Among the few incisedpunctated sherds ( 3.4 percent of the decorated sherd assemblage) is one body sherd with horizontal incised panels with a single row of tool punctations running down the center of the panels (Figure $2 b$ ). Another incised-punctated sherd with crescent-shaped punctations between horizontal incised lines is from a Weches Fingernail Impressed, var. Weches vessel (see Stokes and Woodring 1981). Other utility wares include rim and body sherds with either fingernail or tool punctated rows ( 25 percent of the decorated sherds), and two body sherds ( 2.2 percent of the decorated sherd assemblage) with broad and shallow trailed lines.

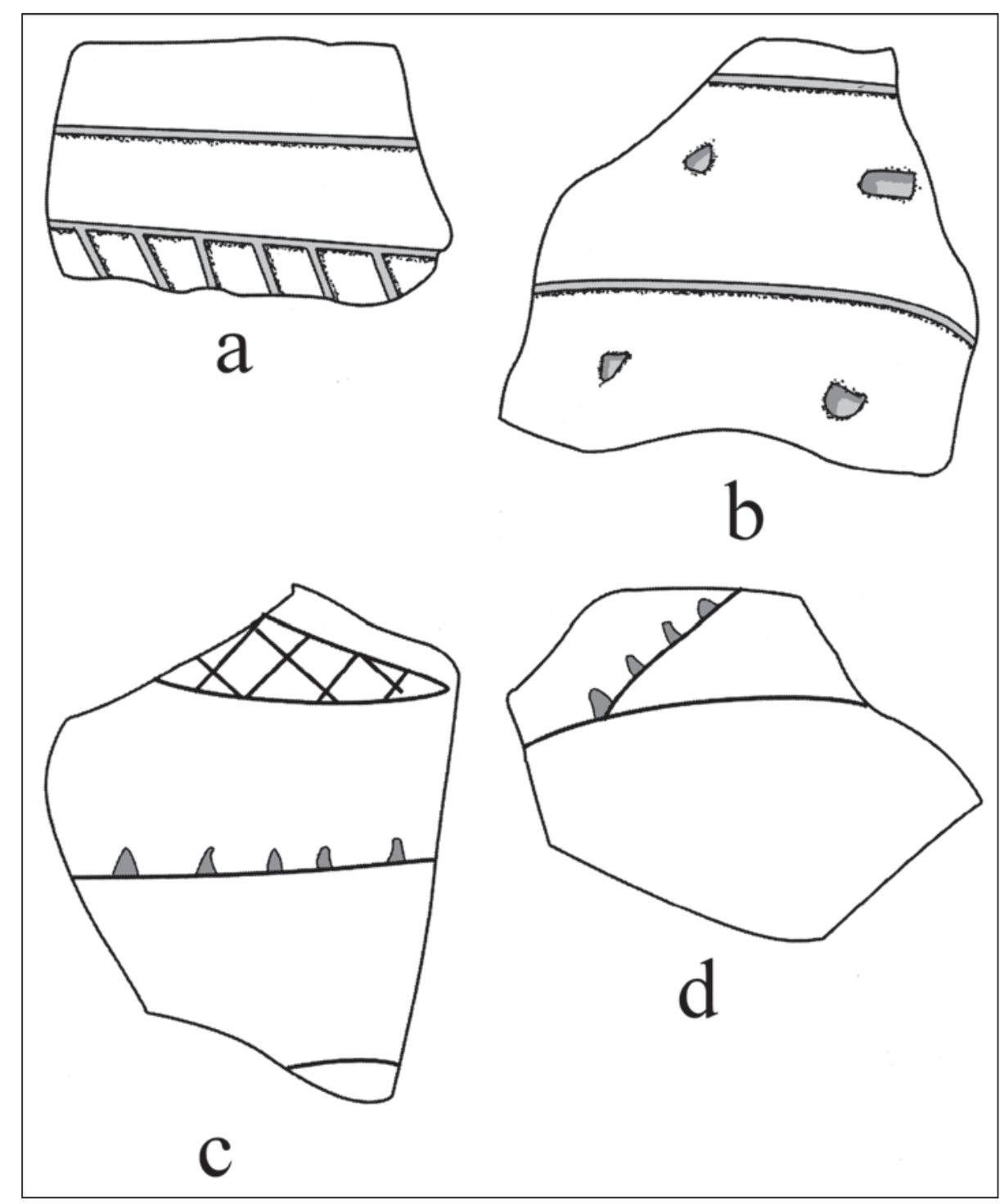

Figure 2. Decorative elements on selected body sherds from the Hill Place: a, incised; b, incised-punctated; c-d, engraved. 
The engraved rim sherds in the Hill Place site assemblage have horizontal, horizontal-diagonal, or diagonal engraved lines (see Table 2), and compare to certain pre-A.D. 1300 fine wares in Angelina River basin sites. Two other sherds (see Figure 2c-d) are not readily categorized, although both have at least one engraved line with small excised tick marks. One sherd may be from a Patton Engraved, var. Fair vessel (see Perttula 2011:Figure 6-66d), but a sherd with more of the motif would be needed to confirm the provisional identification. The other distinctive fine ware sherd has parallel lines, one with excised tick marks and a cross-hatched curvilinear zone (see Figure 2c).

There are also five body sherds and a rim sherd of Goose Creek Plain, var. unspecified, a sandy paste ceramic ware made during the Woodland period in this part of East Texas. These sherds are part of a Woodland period occupation at the site, along with single petrified wood examples of Gary and Godley dart points.

\section{J. B. Dorsey (41NA6)}

The Dorsey site was recorded by Arnold in February 1940, and the small site (0.5 acres) was on a floodplain rise of a small tributary stream; King Creek lies about $1.2 \mathrm{~km}$ to the south. Arnold noted two concentrations of sherds on the surface, which he suggested likely represented two different but related habitation areas.

Arnold collected more than 880 ceramic vessel sherds from the site, while Marceaux (2011:221-228 and Table 6.45) tabulated 995 sherds in the J. B. Dorsey site collection during his detailed analysis of the collection, including a few sherds collected from the site in 2007. This includes 565 brushed sherds and 167 plain sherds in TARL's bulk artifact storage facility; the sample analyzed in detail for this study includes 120 sherds (Table 3). Consequently, the ceramic sherd sample from the J. B. Dorsey site is comprised of 178 plain sherds and 674 decorated sherds, for a total TARL sample of 852 sherds; the plain to decorated sherd ratio is a low 0.26 . Only 7.1 percent of the decorated sherds (but 44 percent of the decorated rim sherds) are from engraved fine ware vessels.

Table 3. Ancestral Caddo ceramic wares from the WPA archaeological survey investigations at the J. B. Dorsey site.

\begin{tabular}{lccc}
\hline Ware & Grog-tempered & Bone-tempered & N \\
\hline Plain & 9 & 2 & 11 \\
Utility & 57 & 4 & 61 \\
Fine & 44 & 4 & 48 \\
\hline Totals & 110 & 10 & 120 \\
\hline
\end{tabular}

In the analyzed sample, 91.7 percent of the sherds are from grog-tempered vessels, and only 8.3 percent of the sherds are from bone-tempered vessels (see Table 3). Including the brushed sherds in TARL's bulk storage facility, 87 percent of the decorated sherds have brushed, brushed-appliqued $(n=7)$, and brushed-punctated $(n=9)$ decorative elements (Table 4$)$. The brushed to plain sherd ratio for the assemblage is 3.30 , and the brushed to other wet paste sherds ratio is 10.1 . 
Table 4. Decorative methods and elements in the ancestral Caddo ceramic wares from the WPA archaeological survey investigations at the J. B. Dorsey site.

\begin{tabular}{llll}
\hline $\begin{array}{l}\text { Decorative method/ } \\
\text { Decorative element }\end{array}$ & Rim & Body & N \\
\hline
\end{tabular}

\section{Utility Ware}

\section{Brushed}

parallel brushed

\section{Brushed-Appliqued}

parallel brushed and large appliqued node parallel brushed and opposed appliqued ridge parallel brushed and straight appliqued fillet parallel brushed and straight appliqued ridge

\section{Brushed-Punctated}

Incised

cross-hatched incised lines

diagonal incised lines

horizontal incised lines

opposed incised lines

opposed curvilinear incised lines

parallel incised lines

straight incised line

$\begin{array}{lll}- & 1 & 1 \\ - & 1 & 1 \\ - & 4 & 4 \\ - & 1 & 1\end{array}$

vertical incised lines

\section{Incised-Punctated}

incised triangle filled with tool punctated rows

horizontal and vertical incised lines above row of tool punctations

\section{Punctated}

tool punctated row beneath the lip

tool punctated rows

\section{1}

$-$

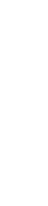

\section{Fine Ware}

\section{Engraved}

curvilinear engraved lines

curvilinear engraved line with excised tick marks

diagonal engraved lines

diagonal hatched zone

diagonal opposed engraved lines

hooked arm el.

$\begin{array}{lll}1 & 1 & 2 \\ 1 & - & 1 \\ 2 & - & 2 \\ - & 1 & 1 \\ - & 2 & 2 \\ - & 13 & 13 \\ - & 6 & 6 \\ 1 & - & 1 \\ & & \\ - & 1 & 1 \\ - & 1 & 1 \\ & & \\ 1 & - & 1 \\ 1 & 10 & \end{array}$


Table 4. Decorative methods and elements in the ancestral Caddo ceramic wares from the WPA archaeological survey investigations at the J. B. Dorsey site, cont.

\begin{tabular}{l|lll}
\hline $\begin{array}{l}\text { Decorative method/ } \\
\text { Decorative element }\end{array}$ & Rim & Body & N \\
\hline
\end{tabular}

\section{Fine Ware, cont.}

\section{Engraved}

horizontal engraved lines

horizontal engraved line with excised tick marks

opposed engraved lines

opposed diagonal engraved lines

opposed diagonal and horizontal engraved lines

panels with diagonal lines and open pendant triangles

parallel engraved lines

parallel engraved lines with excised tick marks

straight engraved line

straight engraved line with excised tick marks

straight engraved line and hatched zone

\section{Engraved-Brushed}

diagonal opposed engraved lines and diagonal brushed body

diagonal opposed engraved lines and horizontal brushed body

horizontal line and curvilinear hatched triangle el.

and diagonal brushing on body

\section{Engraved-Punctated}

hatched vertical zone below row of tool punctates

$\begin{array}{lll}1 & - & 1\end{array}$

Totals

16

93

109

The incised sherds in the J. B. Dorsey assemblage comprise 4.1 percent of the decorated sherds. With the exception of two body sherds with opposed curvilinear lines (Figure 3a-b), the remainder of the rim and body sherds have simple geometric elements, including cross-hatched, diagonal, horizontal, and vertical incised lines on the rim of jars. The incised-punctated body sherds $(0.3$ percent of the decorated sherd assemblage) have either an incised triangle zone filled with tool punctations or a lower rim/body sherd with horizontal and vertical incised lines on the rim and a row of tool punctations at the rim-body juncture (Figure 3c).

About 1.8 percent of the decorated sherds have punctated decorative elements (see Table 4). These have rows of tool punctations on the rim and vessel body.

Among the fine ware sherds from the J. B. Dorsey site are Patton Engraved rim and body sherds $(\mathrm{n}=10)$ (Figure 4a-c), including var. Allen (Perttula 2011:Figure 6-66a), and Poynor Engraved rim and body sherds $(n=6)$ (Figure $4 d-h)$ with engraved, brushed, or punctated elements, from primarily unspecified varieties of the type. These fine wares at the site likely suggest that the J. B. Dorsey site was occupied during the Historic Caddo Allen phase when Patton Engraved vessels were being made and used, as well as sometime during the Late Caddo Frankston phase when Poynor Engraved vessels were primarily made and used. One body sherd with a hooked arm element (see Figure 4d) may be from a Poynor Engraved, Var. $P$ vessel; this variety is known from ca. A.D. 1560-1680 contexts (Perttula 2011:Table 6-37). 


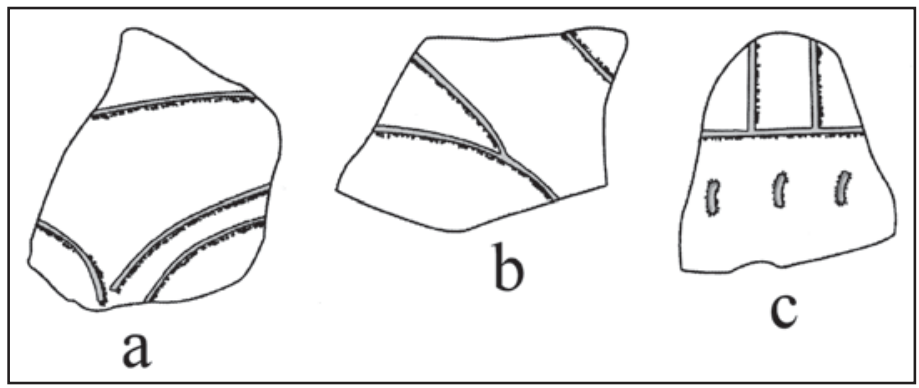

Figure 3. Decorative elements on selected utility ware body sherds from the J. B. Dorsey site: a-b, incised; c, incised-punctated.

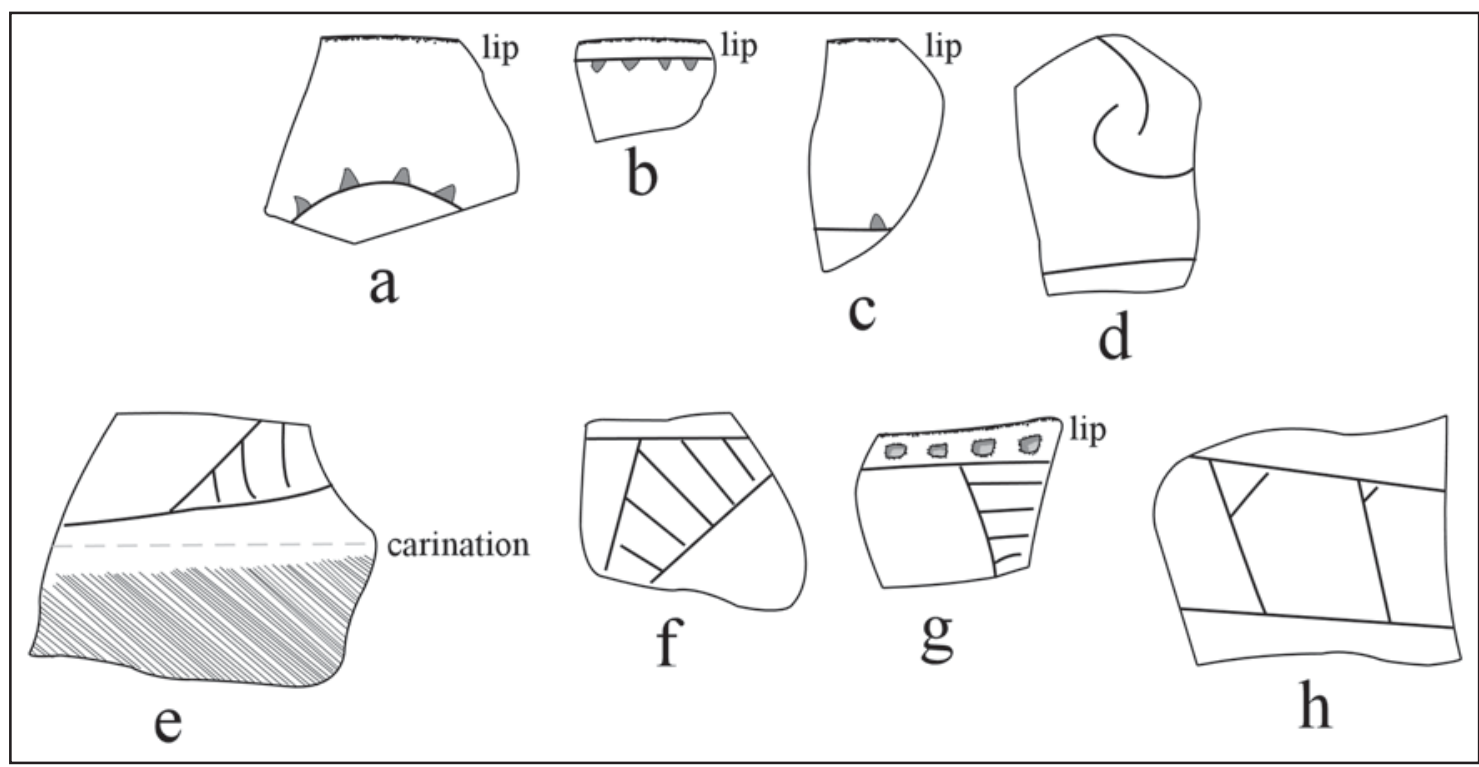

Figure 4. Decorative elements on selected fine ware rim and body sherds from the J. B. Dorsey site: a-c, Patton Engraved rim; d, hooked arm element, Poynor Engraved; e-g, Poynor Engraved; h, engraved panel on Poynor Engraved body sherd.

At least one Poynor Engraved carinated bowl sherd has diagonal brushing marks on the vessel body (see Figure 4e). Two other fine ware carinated bowl sherds of uncertain type from the J. B. Dorsey site have either diagonal or horizontal brushing marks on the vessel body, and diagonal opposed engraved lines on the rim itself.

There are also two sherds from grog-tempered elbow pipes in the J. B. Dorsey site WPA collection, along with a large $(72 \times 46 \mathrm{~mm})$ piece of daub from the remnants of a burned Caddo structure. The pipes are from Neches River elbow pipe forms, either Var. B or Var. C (cf. Perttula 2011:Figure 6-23). A pipe bowl sherd has closely-spaced horizontal incised lines on the lip, while a bowl/stem sherd has two horizontal incised lines along the distal knob of the stem. Such pipes have been documented from Late Caddo period, Frankston phase contexts in upper Neches River basin sites (Perttula 2011:215). 


\section{Deshazo (41NA13)}

What is now known as the Deshazo site (see Story 1982, 1995) was first recorded in November 1939 by Gus Arnold on an alluvial landform at the mouth of Mill Branch in the Bayou Loco drainage. Arnold estimated the site covered a ca. 4 acre area, including a ca. 75 x $50 \mathrm{ft}$. Historic Caddo cemetery excavated by Dr. Robert L. Turner Sr. and his son Robert L. Turner, Jr. Burial features here included ceramic vessels as funerary offerings as well as glass beads, metal knives, and other grave goods (Story 1995:2 and Table 1).

The ancestral Caddo vessel sherd assemblage collected by Arnold includes 84 plain, utility, and fine ware sherds (Table 5). About 82 percent of the sherds are from grog-tempered vessels, and there are bonetempered vessels represented in both the plain wares and utility wares. The plain to decorated sherd ratio in this small assemblage is 1.10; utility wares comprise 95 percent of the decorated sherds.

Table 5. Ancestral Caddo ceramic wares from the WPA survey investigations at the Deshazo site.

\begin{tabular}{lccc}
\hline Ware & Grog-tempered & Bone-tempered & N \\
\hline Plain & 36 & 8 & 44 \\
Utility & 31 & 7 & 38 \\
Fine & 2 & - & 2 \\
\hline Totals & 69 & 15 & 84 \\
\hline
\end{tabular}

Brushed and brushed-incised sherds account for 30 percent of the decorated sherds in the WPA ceramic sherd assemblage (Table 6). Two are from an Historic Caddo type-Spradley Brushed-Incisedthat have parallel brushed marks with overlying opposed parallel incised lines. This utility ware is found on Historic Caddo Allen phase sites in the Neches-Angelina river basins in East Texas. It consists of parallel brushing elements with overlapping straight incised lines that are opposed or perpendicular to the brushing (Marceaux 2011:140 and Figure 5.2).

Table 6. Decorative methods and elements in the ancestral Caddo ceramic wares from the WPA archaeological survey investigations at the Deshazo site.

\begin{tabular}{l|ll} 
Decorative method/ & Rim & Body \\
Decorative element
\end{tabular}

\section{Utility Ware}

\section{Brushed}

horizontal brushed

opposed brushed

parallel brushed

vertical brushed

\section{Brushed-Incised}

parallel brushed with overlying opposed parallel incised lines

\section{Incised}


Table 6. Decorative methods and elements in the ancestral Caddo ceramic wares from the WPA archaeological survey investigations at the Deshazo site, cont.

\begin{tabular}{|c|c|c|c|}
\hline $\begin{array}{l}\text { Decorative method/ } \\
\text { Decorative element }\end{array}$ & Rim & Body & $\mathrm{N}$ \\
\hline
\end{tabular}

\section{Utility Ware, cont.}

\section{Incised}

panel with parallel incised lines

straight incised line

$\begin{array}{lll}- & 1 & 1 \\ - & 1 & 1\end{array}$

\section{Incised-Punctated}

straight incised line and adjacent rows of tool punctates

$\begin{array}{ll}- & 2\end{array}$

\section{Pinched}

vertical pinched ridge

$\begin{array}{lll}- & 1 & 1\end{array}$

\section{Punctated}

single fingernail punctation

single tool punctation

fingernail punctated rows

vertical fingernail punctated row

tool punctated rows

$\begin{array}{lll}- & 1 & 1 \\ - & 3 & 3 \\ - & 1 & 1 \\ - & 1 & 1 \\ - & 8 & 8\end{array}$

\section{Trailed}

parallel trailed lines

$\begin{array}{lll}- & 1 & 1\end{array}$

\section{Fine Ware}

\section{Engraved}

horizontal engraved lines

horizontal engraved lines, one with excised pendant triangle el.

Totals

3

37

40

Twenty percent of the decorated sherds have incised decorative elements. The two incised rim sherds have diagonal incised lines (see Table 6), and one of the body sherds has an incised panel filled with closely-spaced parallel incised lines (Figure 5a). Only 5 percent of the decorated sherds have incisedpunctated elements, and both include rows of tool punctations adjacent to a straight incised line (Figure $5 b)$. There is one Killough Pinched sherd in the WPA collection, and 14 fingernail and tool punctated sherds ( 35 percent of the decorated sherds). One body sherd has broad and shallow trailed lines (see Table 6). 


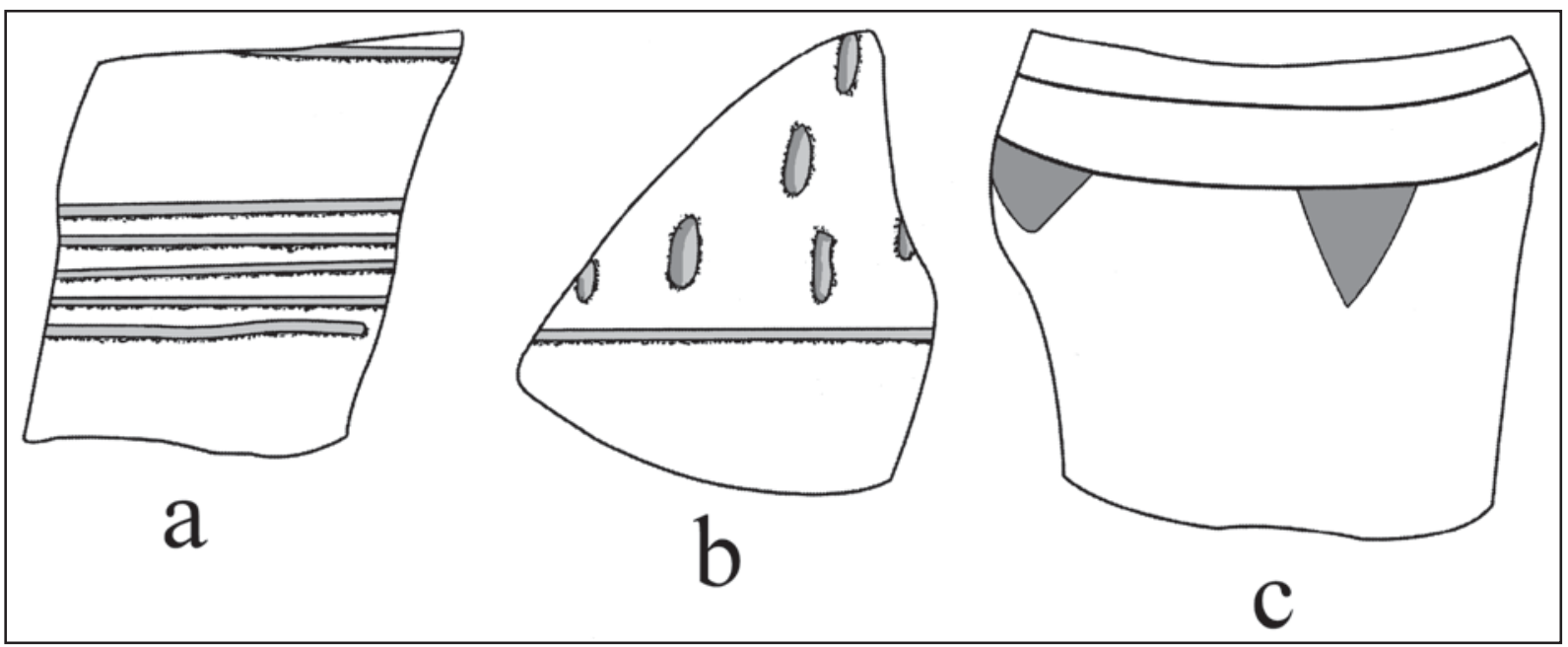

Figure 5. Decorative elements on selected body sherds from the Deshazo site: a, incised; b, incisedpunctated; c, engraved.

Both fine ware sherds are from bottles. The most distinctive is a Hume Engraved, var. Allen body sherd with two horizontal engraved lines on the upper part of the body, the lower one of which has excised pendant triangles (see Figure 5c).

Woodland period Goose Creek Plain, var. unspecified sherds are also in the WPA collection from the Deshazo site. This includes two plain body sherds. Finally, a single brown chert Alba arrow point is in the collections gathered by Arnold in 1939 from the site.

\section{Summary and Conclusions}

The 1939-1940 WPA archaeological survey by Gus Arnold of a number of East Texas counties led to the recording of several hundred ancestral Caddo sites, as well as the collection of substantial amounts of ceramic vessel sherds, as most of the sites were in plowed fields with excellent surface visibility. Despite this, the Arnold collections have been understudied over the years, and only Im (1975) has been a comprehensive, if outdated, consideration of the character of the Caddo ceramic vessel sherd assemblages and their cultural and temporal affiliations. In addition to the recent examination of Arnold vessel sherd assemblages from sites in San Augustine and Sabine counties (Perttula 2015a, 2015b, 2016; Perttula and Walters 2016), I have continued to reanalyze and study other East Texas Caddo ceramic sherd assemblages from other East Texas counties, beginning with the study of sherds from three sites in Nacogdoches County: Hill Place (41NA5), J. B. Dorsey (41NA6), and Deshazo (41NA13).

The Hill Place and Deshazo sites were occupied first in Woodland period times (ca. 500 B.C.-A.D. 800), as denoted by Goose Creek Plain, var. unspecified sandy paste vessel sherds and/or certain Woodland period style dart points. The assemblages of Woodland period material culture remains from these two sites are not large, suggesting that the two sites may have been temporary encampments of huntinggathering peoples. The WPA collections from the Hill Place, J. B. Dorsey, and Deshazo sites have much more substantial ancestral Caddo ceramic vessel sherd assemblages (Table 7), and they are the product of multi-year sedentary occupations by farming families. 
Table 7. Summary comparison of ancestral Caddo WPA ceramic vessel sherd assemblages from the Hill Place, J. B. Dorsey, and Deshazo sites.

\begin{tabular}{llll}
\hline Attributes & Hill Place & J. B. Dorsey & Deshazo \\
\hline \% Bone temper & 33.0 & 8.3 & 17.9 \\
\% Grog temper & 67.0 & 91.7 & 82.1 \\
$\begin{array}{l}\text { No. of Decorated } \\
\text { sherds }\end{array}$ & 89 & 674 & 40 \\
P/DR & 1.37 & 0.26 & 1.10 \\
& & & \\
Decorative Method* & & & - \\
Appliqued & 1.1 & - & 25.0 \\
Brushed & 35.0 & 83.9 & - \\
Brushed-appliqued & 1.1 & 1.0 & 5.0 \\
Brushed-incised & 3.4 & - & - \\
Brushed-punctated & - & 1.3 & 10.0 \\
Incised & 19.1 & 4.1 & 5.0 \\
Incised-punctated & 3.4 & 0.3 & 2.5 \\
Pinched & - & - & 35.0 \\
Punctated & 24.7 & 1.8 & 2.5 \\
Trailed & 2.2 & - & 5.0 \\
Engraved & 9.0 & 6.5 & - \\
Engraved-brushed & - & 0.4 & \\
\hline
\end{tabular}

*in percentage

The relatively high Plain to Decorated sherd ratio (P/DR values of 1.10 and 1.37) and the relatively modest proportion of brushed vessel sherds (30.-39.5 percent) in the WPA ceramic vessel sherd assemblages from the Hill Place and Deshazo sites indicates that they are the product primarily of pre-A.D. 1300 Caddo occupations. Both Fields (1995:229) and Story (1995:237 and Figure 81c) have noted that there are prehistoric - not Historic Allen phase-Caddo components at the Deshazo site, primarily at the southern end of the site. The presence of a Killough Pinched sherd at the Deshazo site also suggests some use of the site during the Late Caddo period Frankston phase. However, at the Hill Place site, an Early Caddo Weches Fingernail Impressed, var. Weches sherd is in the WPA collection, and other sherds there resemble both Reavely Brushed-Incised or Pease Brushed-Incised types.

In the case of the J. B. Dorsey site, the occurrence of some Poynor Engraved sherds, including a Var. P sherd, points to a ca. A.D. 1560-1680 Frankston phase occupation there, but the principal occupation was during the post-A.D. 1680 Allen phase. This latter occupation is marked by the considerable use of grog as a temper for vessel manufacture, a low P/DR (0.26), very high proportions of brushed vessel sherds (87 percent), Patton Engraved fine ware sherds, and the use of ceramic elbow pipes. Marceaux (2011) places the J. B. Dorsey site in a Middle Angelina cluster, and King Creek subcluster, of Hasinai sites in East Texas, and thus a site affiliated with Hainai and Nacogdoche Caddo communities in the region.

By contrast, only a few sherds in the WPA collections at either the Hill Place (Patton Engraved) or the Deshazo sites (Spradley Brushed-Incised and Hume Engraved, var. Allen) are indicative of ancestral Caddo use after ca. A.D. 1680. Both sites have much higher proportions of bone-tempered ceramic vessels (17.9-33.0 percent) than the Allen phase component at the J. B. Dorsey site, as well as higher proportions of non-brushed utility wares, including sherds from vessels decorated with punctated (24.735.0 percent), incised (10.0-19.1 percent), and incised-punctated (3.4-5.0 percent) elements. 


\section{Acknowledgments}

Thanks to Marybeth Tomka at the Texas Archeological Research Laboratory for access to these collections. Lance Trask prepared the figures for this article.

\section{References Cited}

Fields, R. C.

1995 Analysis of Native-Made Ceramics. In The Deshazo Site, Nacogdoches County. Texas, Volume 2: Artifacts of Native Manufacture, edited by D. A. Story, pp. 173-232. Studies in Archeology 21. Texas Archeological Research Laboratory The University of Texas at Austin.

Hart, J. P.

1982 An Analysis of the Aboriginal Ceramics from the Washington Square Mound Site, Nacogdoches County, Texas. Master's thesis, Department of Anthropology, Northeast Louisiana University, Monroe.

2014 An Analysis of the Aboriginal Ceramics from the Washington Square Mound Site, Nacogdoches County, Texas. Stephen F. Austin State University Press, Nacogdoches.

Im, H.-J.

1975 An Analysis of the G. E. Arnold Survey of East Texas. Master's thesis, Department of Anthropology, The University of Texas at Austin.

Marceaux, P. S.

2011 The Archaeology and Ethnohistory of the Hasinai Caddo: Material Culture and the Course of European Contact. Ph.D. dissertation, Department of Anthropology, The University of Texas at Austin.

Perttula, T. K.

2011 The Ceramic Artifacts from the Lang Pasture Site (41AN38) and the Place of the Site within an Upper Neches River Basin Caddo Ceramic Tradition. In Archeological Investigations at the Lang Pasture Site (41AN38) in the Upper Neches River Basin of East Texas, assembled and edited by T. K. Perttula, D. B. Kelley, and R. A. Ricklis, pp. 145-320. Archeological Studies Program Report No. 129, Texas Department of Transportation, Environmental Affairs Division, Austin.

2015a Two Caddo Sites in the Attoyac Bayou Basin in the East Texas Pineywoods, San Augustine County, Texas. Journal of Northeast Texas Archaeology 54:41-53.

2015b Caddo Sites on Patroon, Palo Gaucho, and Housen Bayous in Sabine County in the Sabine River Basin of East Texas. Journal of Northeast Texas Archaeology 54:63-91.

2016 Caddo Ceramic Assemblages from Sites in the Ayish and Palo Gaucho Bayou Basins, San Augustine County, Texas. Journal of Northeast Texas Archaeology 70:13-31.

Perttula, T. K. and M. Walters

2016 The Jonas Short Site (41SA101), San Augustine County, Texas. Journal of Northeast Texas Archaeology 62:19-30.

Stokes, J. and J. Woodring

1981 Native-Made Artifacts of Clay. In Archeological Investigations at the George C. Davis Site, Cherokee County, Texas: Summers of 1979 and 1980, edited by D. A. Story, pp. 135-238. Occasional Paper No. 1. Texas Archeological Research Laboratory, The University of Texas at Austin. 
Story, D. A. (editor)

1982 The Deshazo Site, Nacogdoches County, Texas, Vol. 1: The Site, Its Setting, Investigations, Cultural Features, Artifacts of Non-Native Manufacture, and Subsistence Remains. Texas Antiquities Permit Series No. 7. Texas Antiquities Committee, Austin.

1995 The Deshazo Site, Nacogdoches County, Texas, Vol. 2: Artifacts of Native Manufacture. Studies in Archeology 21. Texas Archeological Research Laboratory, The University of Texas at Austin.

Suhm, D. A. and E. B. Jelks (editors)

1962 Handbook of Texas Archeology: Type Descriptions. Special Publication No. 1, Texas Archeological Society, and Bulletin No. 4, Texas Memorial Museum, Austin. Reprinted in 2009, Gustav's Library, Davenport, Iowa. 